\title{
IDENTIFICATION OF CORONARY ATHEROSCLEROTIC LESIONS IN RAT INDUCED BY INTRAVENOUS CANDIDA ALBICANS
}

\author{
RENDRA CHRIESTEDY PRASETYA*, NADIE FATIMATUZZAHRO, I DEWA AYU SUSILAWATI, \\ AYU PRATIVIA YONENDA
}

Department of Biomedical, Faculty of Dentistry, University of Jember, East Java, Indonesia. Email: rendra.fkg@unej.ac.id

Received: 22 June 2018, Revised and Accepted: 10 August 2018

\begin{abstract}
Objective: This study aimed to identify the sign of coronary atherosclerosis lesion in rat induced by intravenous Candida albicans.

Methods: This research was an experimental laboratories (in vivo) that used 15 male Wistar rat, divided into three groups of the control, the first treatment group injected by $C$. albicans intravenously with concentration of the $10^{-10}$ cells $/ \mathrm{mL}$ and the second treatment group injected by $C$. albicans intravenously with concentration of the $10^{-12}$ cells $/ \mathrm{mL}$. $0.2 \mathrm{~mL}$ of $C$. albicans were injected to the first and second treatment group on $1^{\text {st }}, 4^{\text {th }}, 9^{\text {th }}$, $16^{\text {th }}$, and $23^{\text {rd }}$ day. On the $5^{\text {th }}$ week, rats were sacrificed, taken its hearts that contained the coronary artery. Rat's heart had been fixed; histological preparations were made and painted with Picrosirius Red and Sudan IV, observed by a microscope.
\end{abstract}

Results: The artery walls of the first and second treatment group were thicker than the control group. Lesions and disposition lipids of the first and second treatment group were more frequent than the control group.

Conclusion: Intravenous C. albicans can increase the risk of coronary atherosclerosis.

Keywords: Atherosclerotic lesion, Candida albicans, Coronary artery, Systemic candidiasis.

(C) 2018 The Authors. Published by Innovare Academic Sciences Pvt Ltd. This is an open access article under the CC BY license (http://creativecommons. org/licenses/by/4. 0/) DOI: http://dx.doi.org/10.22159/ajpcr.2018.v11i12.28062

\section{INTRODUCTION}

Atherosclerosis is the largest health problem in the world [1]. Atherosclerosis occurs in arteries including the aorta and coronary arteries, femoral, iliac, carotid intera, and cerebral. Atherosclerosis in the coronary arteries is the main trigger of death because it can cause heart failure in pumping blood which can stop the blood supply throughout the body [2]. The pathogenesis of atherosclerosis is unidentified in certain yet. More than 20 epidemiological studies conducted in many countries to this day prove that there is a connection between the food and the lipid atherosclerosis $[3,4]$.

Lipid peroxidation, due to free radical activity, plays an important role in the development of atherosclerosis. Free radicals in the presence of oxygen may cause degradation (peroxidation) of lipids within plasma and organellar membranes. Oxidative damage is initiated when the double bonds in unsaturated fatty acids of membrane lipids are attacked by oxygen-derived free radicals particularly by $\mathrm{OH}$ [5]. Oxidative damage of lipid, especially low-density lipoprotein (LDL) in the arterial wall, can lead proliferation and migration of smooth muscle cells [6].

In the last few years, it has been developed a paradigm that infection with bacteria, viruses, and other microorganisms contributes to the formation of plaque atherosclerosis [3]. Fungal infections Candida albicans are one of the suspected infections which contribute to the formation of plaque atherosclerosis $[7,8]$. Opportunistic pathogen Candida is a species that can cause infections in the superficial mucosa to spread to the blood vessels, causing injury to the endothelium and stimulates autoimmune [9].

This research shows that there is a connection between candida infections with lesions of atherosclerosis that is supported by the results of research which states that there is DNA of $C$. albicans in 58\% of coronary heart disease patient samples identified by the method of polymerase chain reaction (PCR) [10]. 67.7\% of patients with stenosis the coronary artery have a Candida colony in its oral cavity [11]. Although it is well known that $C$. albicans is associated with atherosclerosis, there are only few studies talking about the experimental causal effects of the role of $C$. albicans in atherosclerosis. This raises the writer's desire to conduct an experimental study to determine the effect of $C$. albicans on the formation of atherosclerotic lesions.

\section{METHODS}

This study has been approved by the Medical Research Ethics Committee of the Faculty of Medicine, University of Jember. The object of the study was 15 healthy male Wistar rats, with the age of 3-4 months. Rats were divided into three groups: A control group (no treatment), Candida 1 (injected with C. albicans in the concentration of $10^{-10}$ cells $/ \mathrm{mL}$ ), and Candida 2 (injected with C. albicans in the concentration of $10^{-12}$ cells $/ \mathrm{mL}$ ) with each group of five rats. Standard feed was given daily.

\section{Induction of $C$. albicans intravenous}

Rats had been adapted, treated according to the group. Injection of C. albicans (ATCC 10231) was performed on the vein of the tail (lateral vein) in about $0.2 \mathrm{~mL}$ at days $-1,4,9,16$, and 23 .

\section{Histological sample preparation}

At week 5, the rats were sacrificed, performed thoracic surgery and the heart which contained coronary arteries were taken. After that, coronary arteries were fixed using frozen section cutting method which then was painted using Picrosirius Red and Sudan IV with counter Mayer's hematoxylin. Preparation of blood smearing with Giemsa was used to see leukocyte cells that are a sign of systemic candidiasis.

\section{Atherosclerosis parameters}

The observations of atherosclerosis included coronary artery wall thickness, presence of cap, and lipid deposition. Wall thickness and 
atherosclerotic cap detection were observed in histological preparations with Picrosirius Red painting using a $\times 400$ light magnification microscope. The thickness of the coronary artery wall $(\mu \mathrm{m})$ was measured from the intima tunica to the media. The morphology of cap was illustrated by a bumpy surface on the inside (luminal) of the coronary arteries. Detection of lipid deposition was performed on histological preparations with Sudan IV painting and observed it using a light microscope at $1000 \mathrm{x}$ magnification. Lipid deposition was characterized by red color on coronary artery preparations.

\section{Data analysis}

This study produces qualitative data (the presence of lipids and lipid deposition) and quantitative data in the form of measurements of coronary artery wall thickness. Qualitative data were analyzed by nonparametric difference Kruskal-Wallis test, followed by Mann-Whitney test data $(\mathrm{p}<0.05)$. The quantitative data were analyzed by parametric test of independent one-way ANOVA, then continued with post hoc test to know the group of samples that gave significant value $(\mathrm{p}<0.05)$.

\section{RESULTS}

Systemic candidiasis in experimental animals

C. albicans induction caused systemic infection that was proved by examination of leukocyte cells in blood smear with Giemsa staining, and it was observed with a $\times 400$ magnification light microscope (Fig. 1). The number of leukocytes in the Candida 1 group was higher than in Candida 2 and control group.

\section{Measurement of the coronary arterial thickness wall}

The result showed that Candida 1 had the thicker average than the other groups. Data were analyzed with one-way ANOVA. It was found that coronary artery wall between groups was significantly different $(\mathrm{p}<0.05)$ (Table 1). Post hoc test showed that group Candida 1 was significantly different $(\mathrm{p}<0.05)$ compared to control group, but there was no significant difference between Candida 2 group with control and Candida 1 group (Table 2).

\section{Observation of atherosclerotic cap and lipid deposition}

Histological features show that groups of Candida 1 and 2 were found in morphology of lipid. All groups have a lipid deposition profile. The presence of cap is characterized by a bumpy formation of bulge on the inner side (luminal) of the coronary arteries (Fig. 2). Candida 1 group has the highest percentage of atherosclerotic cap and lipid deposition. Kruskal-Wallis test showed that there were significant differences between the groups $(\mathrm{p}<0.05)$ (Table 3$)$, followed by Mann-Whitney test showed that Candida 1 group was significantly different to control $(\mathrm{p}<0.05)$, whereas Candida 2 group with control and Candida 1 did not differ significantly $(\mathrm{p}>0.05)$ (Table 2$)$.

\section{DISCUSSION}

This study showed that the effect of $C$. albicans infection induced the formation of coronary atherosclerosis lesions. The degree of systemic candidacies infection is evidenced by the examination of leukocyte cells in the blood smear. Leukocyte cell identification results showed differences in the number of leukocyte cells between groups. The group Candida 1 had more leukocytes counts than the other groups; this was because the group of Candida 1 was injected by C. albicans with a higher concentration than the Candida 2 and control group. The increase in leukocytes occurred due to systemic infection of $C$. albicans relating to its role in the cellular and humored defenses of organisms against foreign substances [12]. Shi and Tokunaga report that C. albicans may result in endothelial injury and stimulate an autoimmune reaction [9].

Factors which are affecting the infection process of C. albicans are adhesion, spore changes to hyphae, and extracellular enzyme production. The adhesion of $C$. albicans in spore form involves the interaction between ligand and receptor in endothelial cells. The attachment and physical contact between $C$. albicans and endothelial
Table 1: The average of coronary artery wall thickness (intima media)

\begin{tabular}{lll}
\hline Groups & N & $\begin{array}{l}\text { Wall thickness } \\
\text { average } \mathbf{X} \pm \text { SD }(\boldsymbol{\mu m})\end{array}$ \\
\hline Control & 5 & $6.2 \pm 1.4$ \\
Candida 1 & 5 & $10.1 \pm 1.8$ \\
Candida 2 & 5 & $8.2 \pm 2.4$ \\
One-way ANOVA test Sig.(p) & & $0.002^{*}$ \\
\hline
\end{tabular}

*Significant difference ( $\mathrm{p}<0.05)$. Control: Not induced C. albicans, Candida 1: Induced C. albicans intravenous $10^{-10}$ cells $/ \mathrm{mL}$. Candida 2: Induced C. albicans intravenous $10^{-12}$ cells $/ \mathrm{mL}$

Table 2: Post hoc test for coronary artery wall thickness and Mann-Whitney test for atherosclerotic cap

\begin{tabular}{lll}
\hline Groups & $\begin{array}{l}\text { Post hoc test } \\
\text { Sig. (p) }\end{array}$ & $\begin{array}{l}\text { Mann-Whitney } \\
\text { test Sig. (p) }\end{array}$ \\
\hline Control-Candida 1 & $0.002^{*}$ & $0.002^{*}$ \\
Control-Candida 2 & 0.157 & 0.234 \\
Candida 1-Candida 2 & 0.187 & 0.105 \\
\hline
\end{tabular}

*: Significant difference $(\mathrm{p}<0.05)$. Control: Not induced C. albicans. Candida 1 Induced C. albicans intravenous $10^{-10}$ cells $/ \mathrm{mL}$. Candida 2 : Induced C. albicans intravenous $10^{-12}$ cells $/ \mathrm{mL}$

Table 3: Observations of cap atherosclerotic and lipid deposition on coronary artery

\begin{tabular}{lll}
\hline Groups & $\begin{array}{l}\text { Atherosclerotic cap } \\
\text { percentage (\%) }\end{array}$ & $\begin{array}{l}\text { Lipid deposition } \\
\text { percentage (\%) }\end{array}$ \\
\hline Control & 0 & 50 \\
Candida 1 & 87.5 & 100 \\
Candida 2 & 37.5 & 62.5 \\
Kruskal-Wallis test & $0.002^{*}$ & 0.081 \\
Sig.(p) & &
\end{tabular}

Sig.(p)

*: Significant difference $(\mathrm{p}<0.05)$. Control: Not induced C. albicans. Candida

1: Induced C. albicans intravenous $10^{-10}$ cells $/ \mathrm{mL}$. Candida 2 : Induced C. albicans intravenous $10^{-12}$ cells $/ \mathrm{mL}$

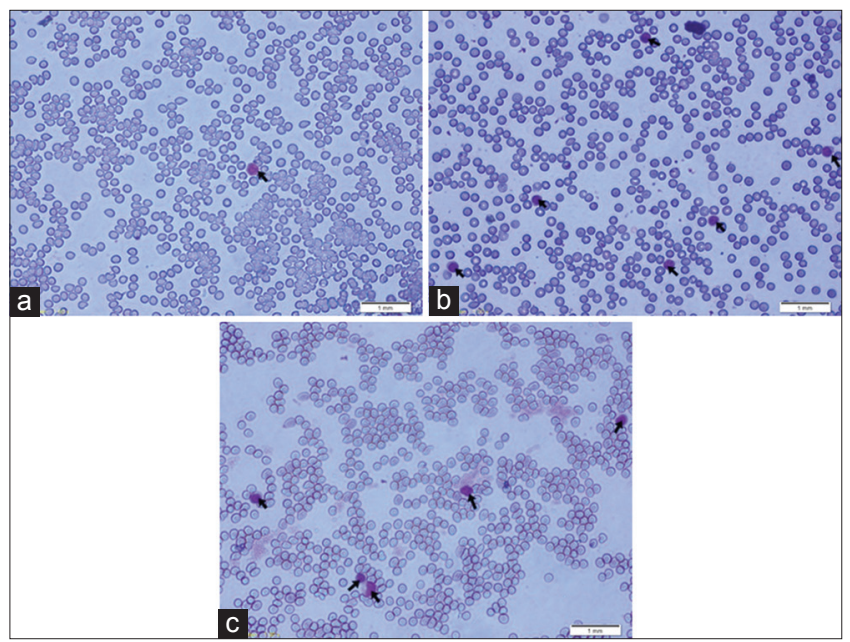

(Fig. 1: Leukocyte cells, with Giemsa stain (amplification ×400) in rats blood smear. Control group (a), the number of leukocyte is normal. The increase in the number of leukocyte cells higher in Candida 1 group (b) than Candida 2 (c) (black arrow)

cells will activate the MAP-kinase necessary for invasive hyphae development and biofilm development. The hyphae form and extracellular enzyme aspartyl proteinase will facilitate $C$. albicans to invade endothelial cells to form holes in endothelial cells. The invasion 


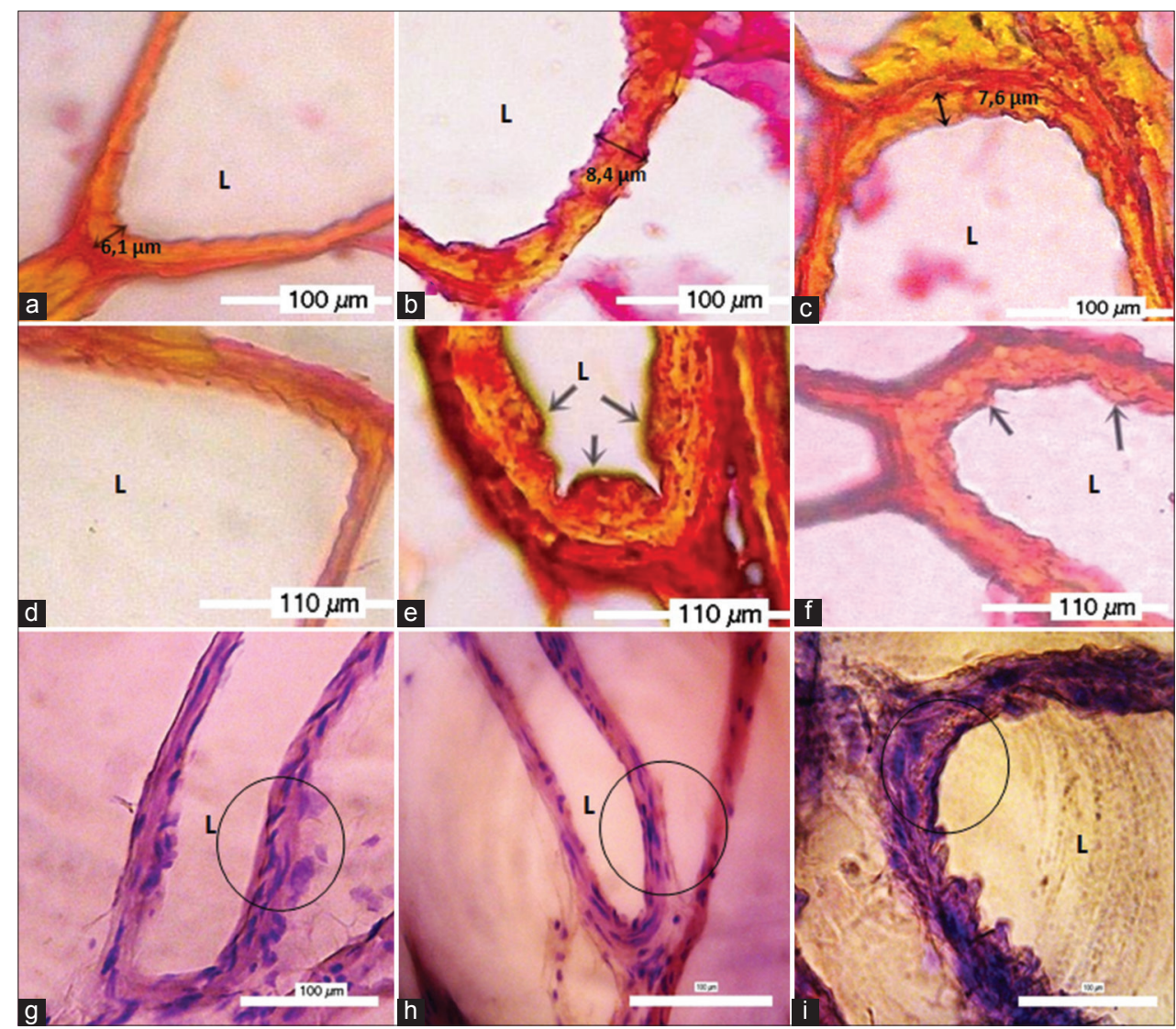

Fig. 2: Histological coronary artery using Picrosirius Red staining $(\times 1000)$. Control group wall thickness of $6.1 \mu \mathrm{m}(\mathrm{a})$. Candida 1 group wall thickness of $8.4 \mu \mathrm{m}$ (b). Candida 2 group wall thickness of $7.6 \mu \mathrm{m}$ (c). Atherosclerotic cap, in the control group (d) was not found. Candida 1 (e) and Candida 2 (f) were found atherosclerotic cap (black arrow). In the control group (g), Candida 1 (h) group and Candida 2 (i) group were found morphology of lipid deposition (dark circle) (Sudan IV staining; ×1000). L = Lumen

of hyphae leads to vascular inflammation that induces an increase in the number of leukocytes [13-15].

The results showed that there was an effect of $C$. albicans infection that was injected intravenously to the formation of coronary atherosclerosis lesion seen from three parameters, i.e., coronary artery wall thickness, the presence of cap coronary artery, and foam cell in coronary artery wall. The results of this study are supported by previous epidemiological studies that prove that fungal infection of $C$. albicans is associated with an increased risk of developing cardiovascular disease [10-11,16]. Jegier et al. explained that there is DNA C. albicans in $58 \%$ of samples of patients with coronary heart disease identified by the PCR method [10].

The measurement results showed coronary artery thickening in the Candida group compared to the control group. The thickening of the coronary arteries is due to endothelial dysfunction caused by endothelial injury. It happens because there is hyphae penetration of C. albicans into the blood vessels. Endothelial dysfunction will express certain adhesion molecules, which facilitate leukocytes, monocytes, and T-lymphocytes to attach to the arterial wall and penetrate the intima with the help of monocyte chemoattractant protein-I and T-cell chemoattractant. Monocytes will differentiate and become active macrophages, so they can secrete pro-inflammatory cytokines and growth factors that also play a role in the thickening of artery walls. Macrophages will perform phagocytosis in LDL-oxidized (ox-LDL) to form a foam cell. The presence of foam cells in the subintimal layer and the increasing number of monocytes or macrophages leads to adaptive thickening of artery walls $[17,18]$. The ratio of coronary artery wall thicknesses is not different significantly between the groups of Candida 2 and the Candida 1 and control groups; it is possibly due to the concentration of $C$. albicans in the group of Candida 2 is too low and close to the group of Candida 1 so that the systemic severity is less visible [19].

The results of the identification of coronary artery limbs in this study show that in the treatment group 1, it was found more cap than other groups. Cap in the arteries is formed due to the accumulation of inflammatory cells, foam cells, necrotic cells, calcium, and smooth muscle cells. Inflammatory cells, especially T-lymphocytes, are increased due to endothelial dysfunction caused by vascular inflammation. T-lymphocytes along with growth factor will induce the proliferation of smooth muscle cells which is the largest composition of the cap coronary artery $(68 \%)[20,21]$. At the time of atherosclerosis process progresses, endothelial cells, macrophages, and smooth muscle cells develop apoptosis or necrosis into necrotic cells that will make cap get worse. The process of calcification in the blood vessels also occurs and affects the formation of the cap, but this process is influenced by the age factor. Increasing age causes the calcium metabolism (calcium) disturbed. It makes much calcium circulates with blood (hypercalcidemia) and deposits in the blood vessel wall [22-24].

This study found morphology of lipid deposition in all groups, especially in the group Candida 1. Lipid deposition is an accumulation of foam cells formed due to the response of vascular inflammation caused by C. albicans. Vascular inflammation causes endothelial dysfunction which can cause the increase of endothelial permeability. This process makes the entry of LDL into the arterial wall, and it is oxidized by reactive oxygen species to be ox-LDL. Endothelial dysfunction increases pro-inflammatory cytokines IL- 1 and TNF- $\alpha$ production. Those substances induce adhesion molecule interstitial cell adhesion molecule and vascular cell adhesion molecule-1 expression on the endothelial layer. This makes monocytes easier to attach to the 
surface of endothelial. The attached monocytes migrate among cells on intercellular junction with the help of platelet endothelial cell adhesion molecule-1 to the subendothelial layer. Monocytes will differentiate into macrophage [25]. Ox-LDL will be phagocyted by macrophages through the scavenger receptor (predators) in the cell surface. That causes the formation of peroxide lipid facilitating the accumulation of cholesterol that forms the foam cell. The foam cells are the agents which form lipid deposition subendotel $[26,27]$. Lipid deposition is an early symptom of atherosclerosis and is triggered by several factors, one of the factors is age. This is the reason why the deposition of lipids was also found in the control group. Elderly age may increase the risk of oxidative stress that can decrease the bioavailability of nitric oxide (NO). The decreasing levels of NO cause vasoconstriction of blood vessels and endothelium to be more proaterogenic [28-30].

\section{CONCLUSION}

This research shows that an intravenous induction of $C$. albicans can increase of atherosclerotic lesions in the coronary arteries characterized by the thickening of the walls of the coronary arteries, cap morphology, and lipid deposition in the coronary arteries.

\section{AUTHORS' CONTRIBUTION}

Rendra Chriestedy Prasetya conducted this research, Nadie Fatimatuzzahro and I Dewa Ayu Susilawati planted and designed this study. The last, Ayu Prativia Yonenda supported the conduction of the study.

\section{CONFLICTS OF INTEREST}

All authors declare that they have no conflicts of interest.

\section{REFERENCES}

1. Libby P. Prevention and Treatment of Atherosclerosis in Harrison's Principles of Internal Medicine. $16^{\text {th }}$ ed. Vol. II. US: The McGraw-Hill Companies US; 2005.

2. Ross R. Aterosclerosis and Inflammatory Disease. New England: Med; 2004.

3. Michael ER, dan Lee Ann C. Pathogens and Atherosclerosis: Update on the Potensial Constribution of Multiple Infectious Organisms to the Pathogenesis of Atherosclerosis. Washington USA: Schattauer Thromb Haemost; 2011.

4. Price SA, Wilson LM. Patofísiology: Konsep klinis Proses-Proses Penyakit. $6^{\text {th }}$ ed. Jakarta: EGC; 2005.

5. Sireesha K, Rao PS. Oxidative stress and diabetes: Overview. Asian J Pharm Clin Res 2015;8:15-9.

6. Kartika Y, Bangun H, Rosidah R. Effect of sodium alginate of prevention of hypercholesterolemia and atherosclerosis in rats. Asian J Pharm Clin Res 2017;11:242-7.

7. Akpan A, Morgan R. Oral candidiasis. Postgrad Med J 2002;78:455-9.

8. Zunt LS. Oral candidiasis: Diagnosis and treatment. The J Prac Hyg 2000;66:252-6.

9. Shi Y, Tokunaga O. Chlamydia pneumoniae (C. pneumoniae) infection upregulates atherosclerosis-related gene expression in human umbilical vein endothelial cells (HUVECs). Atherosclerosis 2004; 177:245-53.

10. Jegier B, Jaszewski R, Kurnatowski P, Kuba K, Lelonek M. Mycotic DNA in non-atherosclerotic aortic wall of coronary patients is associated with sICAM-1 expression. Circ J 2010;74:749-53.

11. Sarvtin MT, Parsa AM, Kordbacheh P, Hashemi SJ, Mahmoudi M, Daie R, et al. Camparison of oral candida flora in patients with coronary atherosclerosis and healthy people. Zahedan J Res Med Sci 2014;16:40-3.

12. Karnen B, Rengganis I. Immunologi dasar edisi Ilmu penyakit Dalam. $11^{\text {th }}$ ed. Jakarta: Gaya Baru; 2014.

13. Naglik J, Albbrecht A, Bader O, Hube BC. Albicans proteinses and host/pathogen interactions. Cell Microbiol 2004;6:915-26.

14. Kumamoto CA. A contact-activated kinase signals C. albicans invasive growth and biofilm development. Proc Natl Acad Sci USA 2005; 102:5576-81.

15. Javatilake AY, Samarayanake YH, Samarayanake LP. An ultrastructural and a cytochemical study of candidal invasion of reconstituted human epithelium. J Oral Pathol Med 2005;34:240-6.

16. Nurgeldiyeva MJ, Hojakuliyev BG, Muhammedov MB. Correlation of atherogenesis with an infection of $C$. albicans. Int J Clin Exp Med 2014; 7:2137-43.

17. Osterud B, Bjorklid E. Role of monocytes in atherogenesis. Physiol Rev 2003;83:1069-112.

18. Schoen FJ, Cotran RS. Blood vessels. In: Robbins Pathologic Basis of Disease. $9^{\text {th }}$ ed. Philadelphia, PA: Saunders Co.; 2013.

19. Wingard JR, Dick JD, Merz WG, Sandford GR, Saral R, Burns WH. Pathogenicity of Candida tropicalis and Candida albicans after gastrointestinal inoculation in mice. Infect Immunity 1983;29:808-13.

20. Tuttolomondo A, Raimondo DD, Pecoraro R, Arnao V, Pinto A, Licata G. Atherosclerosis and inflamatory disease. Curr Pharm Design 2012;18:4266-88.

21. Erling F. Pathogenesis of atherosclerosis. J Am Coll Cardiol 2006;47:C7-12.

22. Libby P. History of discovery inflammation in atherosclerosis. Am Heart Assoc 2012;32:2045-51.

23. Geng YJ, Libby P. Progression of atheroma: A struggle between death and procreation. Arterioscler Thromb Vasc Biol 2002;22:1370-80.

24. Hoffmann U, Brady TJ, Muller J. Cardiology patient page. Use of new imaging techniques to screen for coronary artery disease. Circulation 2003;108:50-3.

25. Kumar V, Cotran R, Robbins SL. Buku Ajar Patologi. Alih Bahasa: Awal Prasetyo, Brahm, U. dan Toni Priliono. 11 $11^{\text {th }}$ ed. Jakarta: EGC; 2015.

26. Hannson GK. Mechanisms of disease: Inflammation, atherosclerosis, and coronary artery disease: Review literature. N Engl J Med 2005;352:1685-95

27. Selwyn AP, Braunwald E. In: Kasper DL, Fauci AS, Longo DL, Braunwald E, Hauser SL, Jameson JL, editors. Ischemic Heart Disease. $16^{\text {th }}$ ed. New York: McGraw-Hill; 2005.

28. Rose LF, Mealey BL. Periodontics: Medicine, Surgery, and Implants. Saint Louis: Elsevier Mosby; 2006.

29. Agus S, Yanti R. Penyakit Periodontal dan Penyakit Jantung Koroner (Aterosklerosis). Bandung: UNPAD; 2010.

30. Kuzkaya N, Weissmann N, Harrison DG, Dikalov S. Interactions of peroxynitrite, tetrahydrobiopterin, ascorbic acid and thiols. J Biol Chem 2003;278:22546-54. 